\section{Langerhans Cell Histiocytosis of the Cervical Spine in an Adult: A Case Report}

\section{Erișkinde Servikal Vertebra Yerleșimli Langerhans Hücreli Histiositoz: Olgu Sunumu}

\begin{abstract}
We present a case of a 47-year-old-woman with a complaint of cervical pain with paresthetic appearance on her left arm. She was treated with analgetics. Further radiological evaluation because of the persistent pain revealed an osteolytic destruction of the fourth cervical vertebra. The patient underwent anterior cervical corpectomy with total excision of the tumor. Stabilization of the cervical spine was performed. Histology confirmed the diagnosis of Langerhans cell histiocytosis $(\mathrm{LCH})$ of the cervical spine. This case report presents the histopathological evaluation, diagnostic work-up and the treatment procedures, because of rarity of cervical spinal LCH cases in the literature.
\end{abstract}

KEYWORDS: Cervical pain, Langerhans cell histiocytosis, Diagnostic, Therapy

\section{Öz}

47 yaşında kadın olgu, servikal ağrı ve sol kolda his kaybı şikayeti ile hastanemize başvurdu. Analjezik tedavisine yanıt vermeyen ağrı nedeni ile olguya uygulanan radyolojik incelemelerde 4 . servikal vertebra seviyesinde tümöral bir sürece sekonder osteolitik destrüksiyon saptand1. Olguya anterior servikal korpektomi ve fiksasyon ile total tümör boşaltımı uygulandı. Postoperatif histopatolojik tanı, servikal vertebranın Langerhans hücreli histiositoz idi. Servikal spinal Langerhans hücreli histiositoz olgularının nadir görülmesi nedeni ile olgu, histopatolojik ve klinik özellikleri, tedavi seçenekleri açısından literatür eşliğinde sunuldu.

ANAHTAR SÖZCÜKLER: Servikal ağrı, Langerhans hücreli histiositoz, Tanı, Tedavi

\section{Salih SAYHAN ${ }^{1}$ \\ Deniz ALTINEL ${ }^{2}$ \\ Cenk ERGUDEN ${ }^{3}$ \\ Ceren KIZMAZOGLU ${ }^{4}$ \\ Merih GURAY 5 \\ Umit ACAR \\ 1,3,4,6 Dokuz Eylul University, Faculty of Medicine Department of Neurosurgery, Izmir, Turkey \\ 2 Izmir Tepecik Training Hospital, Department of Pathology, Izmir, Turkey \\ 5 Dokuz Eylul University, Faculty of Medicine Department of Pathology, Izmir, Turkey}

Received : 16.12.2008

Accepted : 27.07.2009

Correspondence address: Deniz ALTINEL

Department of Pathology, Izmir Tepecik Training Hospital, Izmir, TURKEY

Phone: +90 5053913181

E-mail: denizaltinel@gmail.com 


\section{INTRODUCTION}

Langerhans cell histiocytosis $(\mathrm{LCH})$ is a clonal proliferation of Langerhans cells occurring as an isolated lesion or as part of a systemic (multifocal) proliferation $(13,14)$. The designation of $\mathrm{LCH}$ replaced the previous nomenclature of the group of diseases termed histiocytosis $X$, which included eosinophilic granuloma (EG), Letterer-Siwe Syndrome, and Hand-Schuller-Christian disease (7, $8,10)$.

$\mathrm{LCH}$ is a rare disease. The lesions of $\mathrm{LCH}$ are most often osseous and frequently occur in the skull. Cervical spinal involvement has been reported in only a handful of cases in the literature $(4,5,8,10$, 11).

We report a case of 47-year-old-woman diagnosed as LCH of the cervical spine with the presence of histopathological evaluation, diagnostic work-up and the treatment procedures.

\section{CASE REPORT}

The patient was a 47-year-old-woman who had intractable cervical pain with paresthetic appearance on her left arm. She was evaluated in a medical center at first where a reduction of left wrist flexion was pointed out. She was first treated by analgesics. Due to the ongoing pain, she was brought to our institute for further evaluation. Phhysical examination revealed minimal cervical kyphosis. However, her neurological examination was unremarkable. She was afebrile and the white blood cell count was normal. Magnetic Resonance Imaging (MRI) and 3-Dimensional computed tomography (3D CT) scan revealed an enhancing mass growing out of the vertebral body and causing destruction of the $\mathrm{C} 5$ body without involving intervertebral disc plate (Figure 1A). 3D CT scans also showed the destructive lesion in more detail. The patient underwent surgery for tumour decompression, stabilization with a mesh cage (Pyramesh, Medtronic Sofamor Danek, Inc, Memphis, TN, US) and anterior plates (Zephir, Medtronic Sofamor Danek, Inc, Memphis, TN, US) between C4 and C6. The tumor was resected completely. (Figure 1B).

Histopathologically, it was characterized by a proliferation of Langerhans cells, which were arranged in sheets. They had abundant eosinophilic cytoplasm and showed indentations on the nuclear membrane. An inflammatory cell infiltrate was accompanying the Langerhans cells (Figure 2). On immunohistochemical evaluation, the diagnosis of LCH was facilitated by diffuse immunoreactivity of S 100 and CD1a (Figure 2).

4 months after the surgery, the patient was treated with chemotherapy. After one-year-follow-up, the patient had no other complaints. No evidence of recurrence or any neurological deficit was identified.

\section{DISCUSSION}

$\mathrm{LCH}$ is a rare lesion occurring as an isolated lesion or as part of a systemic (multifocal) proliferation $(13,14)$. It was first described as histiocytosis X in 1953 as a triad. This triad includes the solitary osseous lesion called an "Eosinophilic Granuloma"; eosinophilic granuloma with clinical symptoms of osteolysis, exophthalmus, diabetes insipitus called "Hand-Schuller-Christian Disease", and the malignant form of dissemination called "Letterer-Siwe Disease" (9). All of these clinical entities feature an abnormal proliferation of histiocytic cell type, that is, Langerhans cells $(8,10)$. The present case was a solitary osseous lesion with no evidence of systemic symptoms.

The etiology of the tumor is still controversial ( 7 , $8,10,13,14)$, although clonal proliferation $(13,14)$, a reactive process or a viral etiology $(7,10)$ have been proposed.

LCH most commonly occurs in the first two decades of life; $80 \%$ of the patients are younger than 10 years old $(7,8,10,12)$. The diagnosis of $\mathrm{LCH}$ in adults is rare $(8,10,12)$. However in our case, the patient was 47 years old. It tends to arise more likely in males $(1,10)$ in contrast to our case. The lesions are most often osseous. The most frequently reported anatomic sites are those in the skull (26\%), vertebra $(7 \%)$, ribs $(12 \%)$, upper and lower jaw $(9 \%)$, and bones of extremities $(11 \%)(4,5,8,10,11)$. Bunch et al. reported that only $14(6.5 \%)$ of 214 cases were located in the spine. Our case is a rare example of $\mathrm{LCH}$ in the spine. In the spine, LCH mainly involves the vertebral bodies, with a predilection for the thoracic spine $(54 \%)$ followed by the lumbar $(35 \%)$ and cervical spine $(11 \%)(4,7)$. Posterior arch involvement is less common $(3,7,8)$. In the present case, the lesion was located in the anterior of the cervical spine.

The most common clinical symptom of cervical spine $\mathrm{LCH}$ is pain and restricted range of motion or 


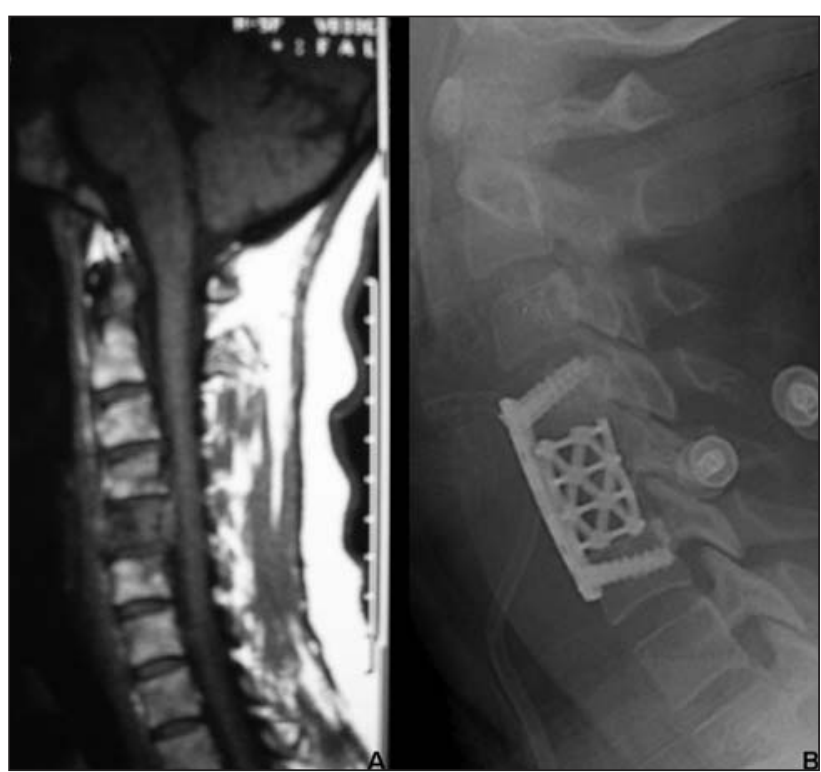

Figure 1: A) Preoperative MRI findings of cervical spine: Sagittal image showing collapsed vertebral body of C5 causing severe kyphosis and subluxation. B) Postoperative lateral $x$ ray, corpectomy cage and anterior plate (C4-6) with screws.

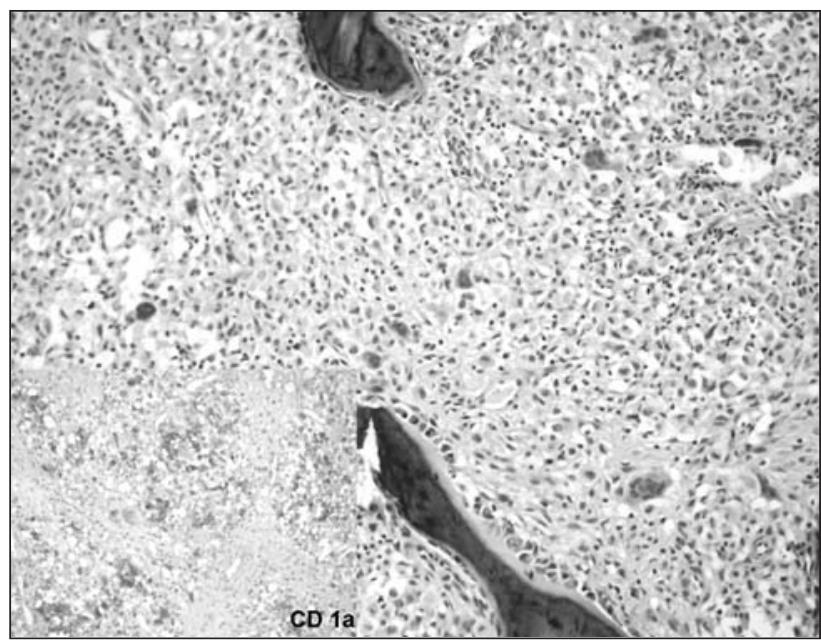

Figure 2: Infiltration of Langerhans cells with oval nuclei and abundant eosinophilic cytoplasm that are intermixed with a few giant cells and lymphocytes $(H-E, X 200)$ and immunoreactivity of Langerhans cells for CD1a (X200).

torticollis (4). In comparison with patients with LCH of the thoracic or lumbar spine, neurological symptoms are less frequent in cervical LCH, whereas muscular symptoms, such as restricted range of motion or torticollis, are seen more often in cervical LCH (4). In the present case, the patient had intractable cervical pain with paresthetic appearance on her left arm and reduced flexion of the left wrist with no neurological symptoms.
Single or multiple sharply-circumscribed osteolytic lesions can be seen by the radiological studies $(3,7)$. When the vertebral column is involved, usually only a single lesion is noted although rarely more than one vertebra can be involved. The disc space is usually preserved and may even appear widened. The lesion is usually confined to the vertebral body and results in anterior wedging or, more commonly, near collapse with a characteristic "vertebra plana" appearance $(7,10)$. In our case, conventional X-ray, CT, MRI scans, and scintigraphic technetium-99 of the whole skeleton were performed and an osteolytic destruction of the fifth cervical vertebra was detected during the workup.

Microscopically, there is a heterogeneous admixture of cells that includes eosinophils, and polymorphonuclear leukocytes, giant cells and mononuclear cells and areas of fibrosis. Many of the mononuclear cells are Langerhans cells, arranged in clusters and diffusely proliferative which is diagnostic (10).

There is a variety of treatment strategies mentioned in the literature. Intralesional corticosteroid injection $(12,15)$ or operative treatment with currettage, operative hemicorpectomy or semitotal corpectomy have been described $(6,12)$. Postoperative chemotherapy or radiotherapy are also mentioned in the literature (6, 12). Spontaneous regression of the bone lesion after 6 months has also been reported $(2,11)$. In our case we performed corpectomy and mesh cage plus anterior plate fixation via the anterior cervical approach (Figure 1B). Postoperatively her complaints decreased eventually. 4 months after the surgery, the patient was treated with chemotherapy (3 cycles of etoposide). After one-year-follow-up, the patient had no other complaints. No evidence of recurrence or neurological deficits has been identified.

\section{REFERENCES}

1. Azouz EM, Saigal G, Rodriguez MM, Podda A: Langerhans' cell histiocytosis: Pathology, imaging and treatment of skeletal involvement. Pediatr Radiol 35:103-115, 2005

2. Bavbek M, Atalay B, Altinors N, Caner H: Spontaneous resolution of lumbar vertebral eosinophilic granuloma. Acta Neurochir (Wien) 146:165-167, 2004

3. Beltran J, Aparisi F, Bonmati LM, Rosenberg ZS, Present D, Steiner GC: Eosinophilic granuloma: MRI manifestations. Skeletal Radiol 22:157-161, 1993 
4. Bertram C, Madert J, Eggers C: Eosinophilic granuloma of the cervical spine. Spine 27:1408-1413, 2002

5. Bunch WH: Orthopedic and rehabilitation aspects of eosinophilic granuloma. Am J Pediatr Hematol Oncol 3:151156, 1981

6. Dickinson LD, Farhat SM: Eosinophilic granuloma of the cervical spine. A case report and review of the literature. Surg Neurol 35:57-63, 1991

7. Kilborn TN, Teh J, Goodman TR: Paediatric manifestations of Langerhans cell histiocytosis: A review of the clinical and radiological findings. Clin Radiol 58:269-278, 2003

8. Kilpatrick SE, Wenger DE, Gilchrist GS, Shives TC, Wollan PC, Unni KK: Langerhans' cell histiocytosis (histiocytosis X) of bone. A clinicopathologic analysis of 263 pediatric and adult cases. Cancer 76:2471-2484, 1995

9. Lichtenstein L: Histiocytosis X; integration of eosinophilic granuloma of bone, Letterer-Siwe disease, and SchullerChristian disease as related manifestations of a single nosologic entity. AMA Arch Pathol 56:84-102, 1953

10. Lieberman $P H$, Jones $C R$, Steinman RM, Erlandson RA, Smith J, Gee T, Huvos A, Garin-Chesa P, Filippa DA, Urmacher C, Gangi MD, Sperber M: Langerhans cell (eosinophilic) granulomatosis. A clinicopathologic study encompassing 50 years. Am J Surg Pathol 20:519-552, 1996
11. Scarpinati M, Artico M, Artizzu S: Spinal cord compression by eosinophilic granuloma of the cervical spine. Case report and review of the literature. Neurosurg Rev 18:209-212, 1995

12. Simanski C, Bouillon B, Brockmann M, Tiling T: The Langerhans' cell histiocytosis (eosinophilic granuloma) of the cervical spine: A rare diagnosis of cervical pain. Magn Reson Imaging 22:589-594, 2004

13. Willman CL: Detection of clonal histiocytes in Langerhans cell histiocytosis: biology and clinical significance. Br J Cancer Suppl 23:S29-33, 1994

14. Willman CL, Busque L, Griffith BB, Favara BE, McClain KL, Duncan MH, Gilliland DG: Langerhans'-cell histiocytosis (histiocytosis X)--a clonal proliferative disease. N Engl J Med 331:154-160, 1994

15. Yasko AW, Fanning CV, Ayala AG, Carrasco CH, Murray JA: Percutaneous techniques for the diagnosis and treatment of localized Langerhans-cell histiocytosis (eosinophilic granuloma of bone). J Bone Joint Surg Am 80:219-228, 1998 